\title{
A patient's diary: episode 13 - In the supermarket
}

\section{DECEMBER}

On Saturday mornings, I generally go down to the High Street and do a bit of shopping for Hilda. I have to pass the Surgery on the way and it's tempting to stop off there, especially if one of my health problems is being troublesome. For several years they actually discontinued the Saturday surgery, which could be really difficult as things have a strange tendency to go wrong with the body at the weekends.

Fortunately the government stepped in and said they should all be open on Saturdays again. They said it was what patients wanted, which is true, but I suspect there may also have been a steep rise in weekend death rates among vulnerable people. The only problem with Saturday surgeries is that there is just one doctor on duty and there is no way of forecasting who it is going to be until you actually get there and can check up on the car park.

This morning, I observed Dr Teacher's new bright red Toyota sitting there in splendid isolation. This was not good news, because I saw him only yesterday, without, I may say, deriving very much satisfaction from the outcome. Once again, we had failed to see eye to eye on the question of my pancreas. So I decided to leave it for today and continue on my way towards the High Street. As well as the pancreatic pain, I have been suffering from some sort of fibromyalgia in the right elbow. This was brought on by carrying last week's shopping in plastic bags because I had forgotten to bring the trolley. This time I did have the trolley, which on the whole runs very smoothly; but you have to apply some leverage to get it over the kerbs when you cross the road and each time I did so I felt a nasty twinge in the inflamed forearm muscles.

Nevertheless, I pushed on, trying my best to ignore all the bubbling and fermenting going on in my pancreas, until I came to the new Health Food Shop and Healing Centre which has replaced the video rental shop. The man in the new place is really very knowledgeable and always tries to be helpful - which is more than can be said for some doctors I could mention. So I parked my trolley outside and went in for a chat. I asked him casually whether he had anything in stock that was good for the pancreas and he said he had just the thing. It was a new vitamin and enzyme preparation which had been specially designed for toning up the digestive organs and correcting imbalance. I bought some of that and my usual muesli and then proceeded on my way, well satisfied, to the supermarket. It was fairly crowded and I had some difficulty locating the right kind of creamed rice for our dessert. Suddenly as I was hunting along the top shelf, a familiar face met my gaze. It was $\mathrm{Dr}$ Brenda, taking advantage of not being on duty to do her weekend shopping!

Our eyes met for a moment and then she was gone. She seemed to move remarkably fast despite the milling crowds but I reacted with alacrity and threaded my way through the meleé, dragging my trolley and ignoring the protests of people who got under my wheels. I finally caught up with her at the delicatessen counter.

'Dr Phillips!' I said. 'What a surprise! Fancy meeting you here! Doing some shopping, are you?' I know it sounds a banal thing to say in the circumstances but I didn't want her to feel that I was immediately going to ask her for some prescriptions as I know many patients would do, given the opportunity. 'Hello, Norman' she said. 'Pretty frantic in here, isn't it?' How are things with you?'

Well, of course, when she asked me directly like that I had to be truthful and not try to conceal the state of my health just because we were in the supermarket. Strangely enough, I read that some supermarkets are starting their own general practice surgeries, so such encounters among the groceries will soon be not uncommon between doctors and patients.

'To be quite frank,' I said, moving a little closer so she could hear me properly, 'I am pretty rotten at present. In fact I was thinking of coming to see you on Monday.' Then I told her about the pancreatic trouble, cutting a long story short as far as possible, but naturally it took a little time to put things in perspective for her and people kept barging past and asking the deli man if their number had been called yet. 'I don't know if you happen to have your prescription pad on you,' I said when l'd finished, 'but it would be a great help if you could just give me something to calm it down over the weekend. And then we can really go into the details when I see you on Monday.' Dr Brenda said she didn't have the pad on her at present and she did have rather a lot of shopping to do; but Dr Teacher was on duty at the surgery and she was sure he would be happy to see me and write a prescription.

We were just saying goodbye when it occurred to me that I ought to tell her about my elbow in case it needed strapping up or anything. Unfortunately, as I was rolling up my sleeve to show her the exact place, some fool - not looking where he was going gave my arm a knock so that my hand shot up and collided with my nose, which began bleeding freely. It's only a few weeks since that nosebleed before Christmas and of course the delicate mucous membrane inside had not had time to heal up. Anyway, Dr Brenda was quite wonderful. Although she wasn't even on duty, she grabbed a box of tissues from a nearby shelf and staunched the haemorrhage with her usual skill.

I had begun to feel a little faint, what with the crowds and the air conditioning and the loss of blood. So she very kindly took me home in her car.

Hilda was rather surprised to see me arriving home in this unusual fashion. She made a remark about it being unsafe to let me out of the house these days which both she had Dr Brenda seemed to find quite hilarious although I failed to see why. The whole experience had been most alarming from my point of view. However, I was consoled by a cup of tea and the comforting thought of those health shop tablets for the pancreas nestling in my pocket.

We are grateful to John Salinsky for these extracts from Norman Gland's diary.

DOI: 10.3399/bjgp08X263947 